\title{
Mechanisms to Protect Human Rights in the EU's External Relations
}

\author{
Yumiko Nakanishi
}

\section{Introduction}

Protection of fundamental rights in the European Union (EU) has developed through the role of the Court of Justice of the EU (CJEU), especially since the 1970s. ${ }^{1}$ The CJEU has relied on constitutional traditions common to the EU Member States and the European Convention for the Protection of Human Rights and Fundamental Freedoms (ECHR), in particular, in order to guarantee fundamental rights in the EU. ${ }^{2}$ The Treaty of Lisbon changed the protection of fundamental rights in the EU. The Treaty made the EU Charter of Fundamental Rights legally binding after the charter was solemnly proclaimed by the various EU organs in 2000. Now, the EU has its own catalogue of fundamental rights, the Charter of the EU Fundamental Rights. The CJEU guarantees fundamental rights in the Union, relying on this instrument, although it is influenced by national (constitutional) courts such as the German Federal Constitutional Court (GFCC) and the European Court of Human Rights (ECtHR).

On the other hand, the CJEU has not played and cannot play an important role regarding protection of human rights in the EU's external relations because of a lack of jurisdiction over third countries. The CJEU is the court of the EU, not an international court. In fact, there are few cases regarding human rights in the EU's external relations. Rather, the legislative and executive organs [the Commission, the Council, and the European Parliament (EP)] are more active in this field. For

${ }^{1}$ CJEU, Case 4/73, Nold v Commission, ECLI:EU:C:1974:51.

${ }^{2}$ CJEU, Case 44/79, Hauer v Land Rheinland-Pfalz, ECLI:EU:C:1979:290.

Y. Nakanishi $(\bowtie)$

Graduate School of Law, Hitotsubashi University, Tokyo, Japan

e-mail: yumiko.nakanishi@r.hit-u.ac.jp 
example, the Council has a specialised body, the Working Party on Human Rights (COHOM), which focuses on international affairs directly related to human rights. ${ }^{3}$ The Council publishes an EU annual report on human rights and democracy in the world. ${ }^{4}$ Wouters and others explain that the restrictive approach of the Court can be understood in part by a desire to protect the integrity and autonomy of the EU legal order, while much of the legislature's openness can be understood in light of the desire of the EU political organs to present the EU as a responsible international actor that shapes developments at the international level. ${ }^{5}$ The High Representative of the EU for Foreign Affairs and Security Policy and the European Commission have published a joint communication document Action Plan on Human Rights and Democracy (2015-2019), titled 'Keeping human rights at the heart of the EU agenda' 6 , and on 20 July 2015, the Council adopted a new 'Action Plan on Human Rights and Democracy' for the period 2015-2019. ${ }^{7}$ The action plan states that the EU will ensure a comprehensive human rights approach to preventing and addressing conflicts and crises, and further mainstream human rights in the external aspects of EU policies in order to ensure better policy coherence. ${ }^{8}$ The protection of human rights is becoming a major plank of EU policies. The above-mentioned joint communication identifies strategic areas of action. One of them is fostering better coherence and consistency. That document states it is necessary to mainstream human rights considerations in the external aspects of EU policies, particularly with regard to trade/investment, migration/refugee/asylum, and development policies, as well as counter-terrorism, in order to ensure better policy coherence. ${ }^{9}$ The EP has a subcommittee for human rights as one of the parliamentary committees. Moreover, the EP has published a Resolution on the Annual Report on Human Rights and Democracy in the World and the European Union's Policy on the Matter 2015. ${ }^{10}$ The EU legislative and executive organs complement and boost the protection of human rights in the EU's external relations and contribute to improving coherence between the EU's internal actions and external actions regarding human rights.

\footnotetext{
${ }^{3}$ http://www.consilium.europa.eu/en/council-eu/preparatory-bodies/working-party-human-rights/ (accessed 23 June 2017).

${ }^{4}$ Annual report on human rights and democracy in the world 2015, thematic part, http://data. consilium.europa.eu/doc/document/ST-10255-2016-INIT/en/pdf (accessed 23 June 2017), and country and regional issues part, http://data.consilium.europa.eu/doc/document/ST-12299-2016INIT/en/pdf (accessed 23 June 2017).

${ }^{5}$ Wouters, Odermatt, and Ramopoulos (2014, p. 276).

${ }^{6}$ The High Representative and the European Commission, JOIN(2015)16, 28 April 2015.

${ }^{7}$ Council of the EU, 10897/15, http://data.consilium.europa.eu/doc/document/ST-12299-2016INIT/en/pdf (accessed 23 June 2017).

${ }^{8}$ Ibid., p. 3.

${ }^{9}$ Ibid., p. 6.

${ }^{10}$ European Parliament, A8-0355/2016, 14 December 2016, Annual Report on Human Rights and Democracy in the World and the European Union's Policy on the Matter 2015, http://www.europarl. europa.eu/sides/getDoc.do?pubRef=-//EP//TEXT+TA+P8-TA-2016-0502+0+DOC+XML+V0// EN\&language $=$ EN (last accessed 23 June 2017).
} 
The Treaty of Lisbon provides a mechanism to protect human rights in the EU's external relations as well as in the EU. This article will show how the Treaty of Lisbon enables the EU to mainstream human rights in the EU's external relations. On the one hand, the Treaty of Lisbon provides the EU's values in Article 2 TEU, its political principles in Article 21 (1) TEU, and its objectives in Article 3 (5) TEU and Article 21 (2) TEU. On the other hand, the Treaty of Lisbon confers new competences to the EU. Furthermore, the combination between the former and the latter enables the Union to conclude not only international agreements, including human rights, but also international human rights agreements. In addition, Article 21 TEU can be used as a means for cross-fertilisation in the context of the protection of human rights. First, the EU's values, political principles, and objectives will be discussed. Second, the article will clarify the competences in the EU's external relations, including international agreements involving or on human rights.

\section{Values, Principles, and Objectives}

\subsection{Protection of Fundamental Rights in the EU}

Before human rights in the EU's external relations are discussed, protection of fundamental rights in the EU are referred to briefly in order to explain the coherence between the EU' internal policies and its external policies. Article 21 TEU requires consistency not only between all external policies but also between external policies and internal policies. ${ }^{11}$

At the beginning of the European Economic Community (EEC) in 1958, the Community sought to achieve economic integration, especially the establishment of a common market. The Community had been criticised because of a lack of a catalogue of fundamental rights. ${ }^{12}$ Owing to the CJEU, fundamental rights are now well guaranteed in the Community (now the Union) after Case 4/73 Nold ${ }^{13}$ in 1974. Since the Treaty of Lisbon, the CJEU can rely on the EU Charter of Fundamental Rights as well as the constitutional traditions common to the EU Member States and the ECHR to guarantee fundamental rights in the EU. Eeckhout argues that the EU system of human rights protection is characterised by the integration of law (the constitutional laws of the Member States and the ECHR). ${ }^{14}$

The CJEU does not hesitate to give a judgement which might be incompatible with international obligations, even those of the United Nations, if such a

\footnotetext{
${ }^{11}$ Cremona (2011a, p. 77).

${ }^{12}$ For example, the so-called Solange I decision by the German Federal Constitutional Court, BVerfGE 37, 285, Order of the Second Senate of 29 May 1974, 2 BvL 52/71. For an English translation, see https://law.utexas.edu/transnational/foreign-law-translations/german/case.php?id= 588 (accessed 23 June 2017).

${ }^{13}$ CJEU, Case 4/73, Nold v Commission, Judgment of 14 May 1974, ECLI:EU:C:1974:51.

${ }^{14}$ Eeckhout (2014, p. 97).
} 
judgement is necessary to protect fundamental rights in the Union. The position of the CJEU is shown in Joined Cases Kadi, where it stated that the obligations imposed by an international agreement cannot have the effect of prejudicing the constitutional principles of the EC Treaty (now the TFEU), which includes the principle that all European Union acts must respect fundamental rights. ${ }^{15}$

Furthermore, what is important for the protection of fundamental rights in the Union is the EU's judicial system. Article 19 (1) TEU ensures a complete judicial system, in particular, through the preliminary ruling procedure in Article 267 TFEU. According to the settled case law of the CJEU, the Treaty establishes a complete system of judicial remedies and procedures designed to ensure the legality of the institutions' acts. ${ }^{16}$ National courts are built into the judicial system to ensure effective legal protection. This is a concretisation of a multi-layered judicial system in a positive way. It can be said that there exists a mechanism to guarantee fundamental rights at the EU level owing to the EU legal order and the EU organs, especially the CJEU.

\subsection{The Treaty of Lisbon and Human Rights in the EU'S External Relations}

The Treaty of Lisbon entered into force on 1 December 2009. It amended existing treaties, that is, the TEC and TEU, substantially. It has changed and is changing the protection of human rights in the EU's external relations. There are two big changes at different levels which are related to them. The first big one is linked to the values and principles of the Union. The second one is combined with amendments on the EU's competences. The second part will be discussed in Sect. 3.

\subsection{Values, Principles, and Objectives}

\subsubsection{Values}

The Treaty of Lisbon gave the Union its own values for the first time. Weatherill observed that there was no values-driven vocation in Treaty of Rome of 1958, but

\footnotetext{
${ }^{15}$ CJEU, Joined Cases C-402/05 P and C-415/05 PJoined Cases C-402/05 P and C-415/05 P, Kadi and AI Barakaat International Foundation v Council, Judgment of 3 September 2008, ECLI:EU: C:2008:461, paras. 285, 326 and 327; CJEU, Joined Cases C-584/10 P, C-593/10 P and C-595/10 P, Commission and others v Kadi, Judgment of 18 July 2013, ECLI:EU:C:2013:518, paras. 22 and 23.

${ }^{16}$ Ex. CJEU, Case C-461/03, Case C-461/03, Gaston Shul Douane-expediteur BV v Minister van Landbouw, Natuur en Voedselkwaliteit, Judgment of 6 December 2005, para. 22, EU:C:2005:742; CJEU, Joined Cases C-402/05 P and C-415/05 P, supra note (15), para. 285; CJEU, Joined Cases C-584/10 P, C-593/10 P and C-595/10 P, supra note (15), para. 22.
} 
the Treaty of Lisbon altered this completely, and with effect from its entry into force, the EU has values. These are written into the Treaties in advance of any engagement with objectives and activities. ${ }^{17} \mathrm{He}$ points out that Article 2 TEU locates 'the EU as a project driven by values' ${ }^{18}$ It is positioned as the highest level of the EU. Cremona analysed the values and first considered values as an integral part of the Union's identity and its constitutional order. ${ }^{19}$ Article 2 TEU lays down the Union's values on which it is founded: respect for human dignity, freedom, democracy, equality, the rule of law, and respect for human rights. Protection of human rights is one of the Union's values. Article 2 TEU commits the EU to respecting human rights. ${ }^{20}$

The EU's values should be respected not only by the EU's organs, but also by the EU Member States. Explicit insertion of the values in the Treaty is meaningful for the EU Member States. For instance, a meaning of the insertion can be found in the following decision of the German Federal Constitutional Court (FGCC) regarding the Comprehensive Economic and Trade Agreement (CETA).

The EU and its Member States and, on the other side, Canada ended negotiations of the CETA. Some citizens and NGOs brought a proceeding, a Preliminary Injunction (einstweilige Anordnung), before the FGCC, claiming that a decision by the Council of the EU authorising the signing of the CETA, its provisional application, and the conclusion of the Agreement violated their rights under Article 38s. 1 of the Basic law (Grundgesetz, GG). ${ }^{21}$ The GFCC declared the judgment on the next day of the oral proceedings, just before the signature of the CETA. The GFCC pointed out that a preliminary injunction preventing German approval of the provisional application of CETA would significantly interfere with the-generally broad-legislative discretion of the Federal Government in the fields of European, foreign, and foreign economic policy and, furthermore, the issuance of a preliminary injunction would have a negative effect on European external policy and the international status of the EU in general. ${ }^{22}$ The GFCC took not only the German interest but also the EU's interest into consideration. Furthermore, the GFCC referred to the Union's values, stating that the international status of the EU was related to the Union's and the Member States' efforts to make the Union's standard a global one in the area of trade relations in order to strengthen the international effectiveness of the Union's values in the EU legal order. ${ }^{23}$ The GFCC recognises

\footnotetext{
${ }^{17}$ Weatherill (2016, p. 393).

${ }^{18}$ Weatherill (2016, p. 393) (emphasis in original).

${ }^{19}$ Cremona (2011b, p. 313).

${ }^{20}$ See Weatherill (2016, p. 128).

${ }^{21}$ BverfG, Urteil des Zweiten Senats vom 13. Oktober 2016, 2 BvR 1368/16, http://www. bundesverfassungsgericht.de/SharedDocs/Pressemitteilungen/EN/2016/bvg16-071.html (accessed 23 June 2017).

${ }^{22}$ Ibid., Rn. 47 and 48.

${ }^{23}$ Ibid., Rn. 48.
} 
well the Union's interest in the standardisation of the EU's norms and the importance of extending the Union's values in the world.

\subsubsection{Principles}

The Treaty of Lisbon systemised the EU's external relations, laying down general provisions on the Union's external actions and specific provisions on the common foreign and security policy in Articles 21-46 TEU and the general provisions of the Union's external actions in Articles 205-222 TFEU. Article 21 (1) TEU provides general political principles for the first time, although respect for human rights and democracy were regulated in Article 177 TEC (former Article 130u TEC) for development cooperation and Article 181a TEC for economic, financial, and technical cooperation. Now, political principles apply to those fields, but also to all external actions. ${ }^{24}$ Article 21 (1) TEU lists the following principles: democracy, the rule of law, the universality and indivisibility of human rights and fundamental freedoms, respect for human dignity, the principles of equality and solidarity, and respect for the principles of the United Nations and international law. The political principles in Article 21 (1) TEU are confirmed in Article 205 TFEU for the EU's external actions.

Some political principles, such as respect for human rights, democracy, and the rule of law, have been used as a condition in the case of giving financial support to developing countries. However, Article 21 (1) TEU applies to all the EU's external actions. It means that the political principles apply to developed countries too.

Indeed, the EU and Canada have concluded a political agreement, a strategic partnership agreement (SPA) ${ }^{25}$, as well as the CETA. It is the first case of the application of political principles to developed countries. Article 2 (1) of the SPA lays down the following:

Respect for democratic principles, human rights and fundamental freedoms, as laid down in the Universal of Human Rights and existing international human rights treaties and other legally binding instruments to which the Union or the Member States and Canada are party, underpins the Parties' respective national and international policies and constitutes an essential element of this Agreement.

According to Article 28 (7) SPA, if there was to be a particularly serious and substantial violation of human rights, it could serve as grounds for the termination of the CETA.

In addition, Article 21 (1) TEU also enumerates respect for the principles of the United Nations Charter and international law as well as human rights as one of political principles and, furthermore, the EU "shall seek to develop relations and build partnerships with third countries, and international, regional or global

\footnotetext{
${ }^{24}$ Nakanishi (2014, p. 18).

${ }^{25}$ OJ of the EU 2016 L329/45, Strategic Partnership Agreement between the EU and its Member States, of the one part, and Canada, of the other part.
} 
organisations which share" its political principles. This provision boosts the Union in protecting human rights in its external relations. The EU can be bound by international agreements, which concretise the political principles. Those agreements might raise the level of the protection of human rights in the EU. In this meaning, Article 21 TEU can be used as an instrument for cross-fertilisation in the context of human rights.

\subsubsection{Objectives}

Articles 3 (5) TEU and 21 (2) TEU set the EU's objectives in its external action.

Article 3 (1) TEU lays down that the Union's aim is to promote peace, its values, and the wellbeing of its people. The promotion of the Union's values is found in Article 3 (5) TEU for the external relations. It says: 'the Union shall uphold and promote its values and interests' and 'shall promote...the protection of human rights...' The above-mentioned decision of the GFCC contributed to this objective as a member state of the EU.

Article 21 (2) TEU states: 'the Union shall define and pursue common policies and actions, and shall work for a high degree of cooperation in all fields of international relations, in order to...(a) safeguard its values, fundamental interests, security, independence and integrity; (b) consolidate and support democracy, the rule of law, human rights and the principles of international law...' Safeguarding the Union's values and consolidating and supporting human rights are considered to be the purposes of the Union.

Larik observed that through the provisions contained in Article 21 TEU, 'the "active paradigm" of EU external relations converges on an emphasis on value promotion on a global scale as well as on approaching the EU's active engagement with the world as an inherent legitimising part of its raison d'être. ${ }^{26}$ Reid points out that the Treaty of Lisbon provides some much-needed clarity regarding the legal basis of the EU's external human rights policy and that there can be no doubt that under Article 21 (2) (b) TEU, the EU has an obligation to pursue the protection of human rights. $^{27}$

A combination of the objectives in Articles 3 (5) TEU and 21 (2) TEU, on the one hand, and their competences, on the other hand, offer the EU the opportunity, and enable it, to protect human rights in the world as well as pursue its internal and external policies.

\footnotetext{
${ }^{26}$ Larik (2014, p. 63) (emphasis in original).

${ }^{27}$ Reid (2015, p. 126).
} 


\section{Competences Regarding Human Rights in the EU's External Relations}

\subsection{Competences and Practice Prior to the Treaty of Lisbon}

The EU is based on the principle of conferral (Article 5 TEU). This means that the EU can act in internal and external policies only within the limits of the competences conferred upon it by the Member States. Although the Maastricht Treaty of 1993 codified the above-mentioned practice of the CJEU in Article F TEU (now Article 6 TEU), that is, in reference to the constitutional traditions common to the Member States and the ECHR, the CJEU clarified in Opinion 2/94 that the Community did not have the competence to accede to the ECHR and that an amendment to the Treaty would be necessary to do this. ${ }^{28}$ Reid has observed that there was a distinction between human rights as a fundamental principle underlying Community actions and policies and the competence to develop a specific human rights policy per se, saying that human rights had been recognised as a general principle of Community law, but there was no specific power of the EU in relation to human rights. ${ }^{29}$

The Maastricht Treaty consolidated constitutionalism in the internal relations of the EU, while also reflecting its development in its external relations. An important change was the introduction of Article 130u TEC (prior to the Treaty of Lisbon, Article 177 TEC, now Article 208 TFEU) for development cooperation and, furthermore, this change led to the introduction of human rights clauses in international treaties concluded by the EU with third countries. ${ }^{30}$ The Community (now the Union) was not given a specific power in the field of human rights. However, this does not mean that international agreements concluded by the Community (now the Union) cannot include human rights clauses. In fact, many international agreements concluded by the EU with third countries include human rights clauses. ${ }^{31}$ Human rights have been considered as an essential element of those agreements. In the case of violation of these rights, the EU can suspend or terminate the agreements. ${ }^{32}$

Furthermore, the CJEU confirmed this in Case C-268/94 Portugal v Council, ruling that Article 130u (2) TEC requires the Community to take account of the objective of respect for human rights when it adopts measures in the field of development cooperation, and the mere fact that respect for human rights

\footnotetext{
${ }^{28} \mathrm{CJEU}$, Opinion 2/94, Accession to the ECHR, Opinion of 28 March 1996, ECLI:EU: C:1996:140.

${ }^{29}$ Reid (2015, p. 120).

${ }^{30}$ Nakanishi (2014).

${ }^{31}$ Ex. Nakanishi (2014, p. 13); Bartels (2015, pp. 74-81).

${ }^{32}$ The procedure of suspension is regulated by Article 218 (9) TFEU; see Koutrakos (2015, p. 155).
} 
constitutes an essential element of the related Agreement does not justify the conclusion that provision goes beyond the objective stated in Article $130 \mathrm{u}$ (2) TEC. $^{33}$

\subsection{Relationship Between Values, Objectives, and Competences}

The Member States confer the Union with competences to attain objectives in the Treaties (the TEU and the TFEU) (Article 1 (1) TEU). Then, the EU can act based on the principle of conferral in the field of external policies as well as that of internal policies. Even if the EU is not given external competences explicitly in the Treaties, it can negotiate and conclude international agreements with third countries and international organisations, using the so-called implied powers under the certain conditions (Article 3 (2) TFEU and Article 216 (1) TFEU). Furthermore, if the EU has exclusive external competences (ex. Article 207 TEU) or exclusive implied competences under the fulfilment of the conditions (for example, in cases that an agreement is likely to affect common rules), it can conclude international agreements alone without any participation of the EU Member States. On the other hand, even if the EU does not have exclusive explicit or implied competences, but shared competences, it can conclude agreements together with the EU Member States. In that case, concluded agreements will be mixed agreements. What is important for the concluding of international agreements is that the EU is given competences. The EU cannot extend its external competences based on the EU's values, principles, or objectives to conclude them even if the subject matter is related to the protection of human rights.

The EU values in Article 2 TEU are abstract and it is difficult to define them in practice. ${ }^{34}$ They can be interpreted widely. However, the EU values cannot be used to extend the Union's competences. The EU's competences are based on the principle of conferral. Neframi indicates that the CJEU has been given a role of exercising the constitutional function of patrolling the vertical division of competences between the EU and the Member States. In the field of the EU's external actions, it must ensure respect for the principle of conferral while pursuing the objective of unity in the international area ${ }^{35}$, although Murswiek insists that the EU competences have been extended by the EU organs. ${ }^{36}$ Herlin-Karnell also points out that the extension of the EU's values requires careful consideration from the perspective of the proper monitoring of EU competences. ${ }^{37}$ He notes that there is a

\footnotetext{
${ }^{33}$ CJEU, Case C-268/94, Portugal v Council, Judgment of 3 December 1996, ECLI:EU: C:1996:461, paras. 23-24; see Koutrakos (2015, pp. 67-70); Reid (2015, pp. 124-126).

${ }^{34}$ Leino (2008, p. 263).

${ }^{35}$ Neframi (2014, p. 73).

${ }^{36}$ Murswiek (2011, p. 787).

${ }^{37}$ Herlin-Karnell (2014, p. 95).
} 
constitutional dimension here, anchored in the question of what the EU is empowered to do, and, in this regard, the reference to 'values' as a means of justification is difficult to monitor. ${ }^{38}$

The objectives listed in Article 21 (2) TEU are comprehensive. However, they cannot be used to justify a means to enlarge the EU's competences. Neframi clarifies that while substantive specific objectives correspond to specific external action competences conferred on the Union in Part V TFEU, the objective to promote an international system based on stronger multilateral cooperation and good global governance in Article 21 (2) (h) TEU is not linked to a specific competence of the Union. ${ }^{39}$

The Union cannot derive its competences to conclude international human rights agreements from the EU's values in Article 2 TEU, the political principles in Article 21 (1) TEU, or the objectives in Article 3 (5) TEU and Article 21 (2) TEU.

\subsection{Two Types of International Human Rights Agreements}

There are two types of international agreements in relation to human rights. ${ }^{40}$ The first type is international agreements which include human rights provisions. This means that the protection of human rights forms a part of those agreements, but it is not the main subject matter. The second type is international agreements on human rights. This means that the subject matter of those agreements is related to human rights.

The Community (now the Union) had no specific competence to conclude international agreements on human rights. On the other hand, especially since the Treaty of Maastricht, the EU has concluded international agreements with human rights clauses as their essential element in the context of its development policy, enlargement policy, and neighborhood policy, as well as of economic and technical cooperation. ${ }^{41}$ This means that the Union can conclude international agreements which govern human rights protection.

\subsection{International Agreements with Human Rights Provisions}

\subsubsection{Horizontal Clause for Human Rights}

The EU cannot rely on the EU's values, principles, or objectives to extend or create its competences. However, this does not mean that the EU cannot conclude

\footnotetext{
${ }^{38}$ Ibid., Herlin-Karnell (2014, p. 95).

${ }^{39}$ Neframi (2014, p. 73).

${ }^{40} \mathrm{Cf}$. Eeckhout (2004, p. 470).

${ }^{41}$ For example, Nakanishi (2014, p. 13); Bartels (2015, pp. 74-81).
} 
international agreements which lay down the protection of human rights. Neframi indicates that the global approach to external action objectives in Article 21 TEU and Article 205 TFEU implies that specific objectives can also be pursued incidentally through the exercise of an external competence corresponding to another main specific objective, whether external or internal. ${ }^{42}$ This leads to the idea that human rights can be pursued incidentally. As mentioned above, many international agreements concluded by the EU contain human rights clauses. Now, the EU has more possibilities of concluding international agreements, including human rights ones, applying its values, principles, and objectives, which the Treaty of Lisbon inserted in Articles 2, 3, and 21 TEU because those provisions function as horizontal clauses. This is explained as follows.

There are some horizontal clauses contained in the Treaties, for example, Article 11 TFEU for environmental protection and Article 13 TFEU for animal welfare.

Article 11 TFEU lays down the principle of environmental integration. It is a horizontal clause. According to the principle, 'environmental protection requirements must be integrated into the definition and implementation of the Union's policies and activities, in particular with a view to promoting sustainable development'. As a result, measures regarding protection of the environment are based on not only Article 192 TFEU but also on other legal bases, such as Article 43 TFEU, Article 114 TFEU, and Article 194 TFEU. Theoretically, the Commission, the Council, and the European Parliament must apply environmental aspects to all the Union's internal and external policies. In fact, the concept of sustainable development can also be found in international trade agreements. ${ }^{43}$

Article 13 TFEU is a horizontal clause on animal welfare: the Union and the Member States must pay full regard to the welfare of animals as sentient beings in the field of agriculture, transport, the internal market, and so on. The EU does not have a specific competence for animal welfare, but many measures regarding animal welfare have been adopted. ${ }^{44}$ Furthermore, international agreements which the EU concluded or is negotiating with third countries have provisions that refer to animal welfare. ${ }^{45}$

Meanwhile, protection of human rights is one of the EU's values in Article 2 TEU and one of the political principles of Article 21 (1) TEU. The protection of human rights is regulated by Article 177 TEC, which deals with development cooperation. EU measures were adopted in order to organise Union activity aimed at fostering respect for human rights in third countries. ${ }^{46}$ The CJEU confirmed in Case C-268/94 Portugal v Council ${ }^{47}$ that EU measures in the field of development

\footnotetext{
${ }^{42}$ Neframi (2014, p. 90).

${ }^{43}$ See Bartels (2015, pp. 82-88).

${ }^{44}$ Nakanishi (2016a, pp. 88-91, pp. 101-104 and pp. 109-111).

${ }^{45}$ For details, Nakanishi (2016b, pp. 138-142).

${ }^{46}$ Dashwood (2008, p. 85 and footnote 44).

${ }^{47}$ CJEU, Case C-268/94, Portugal v Council, Judgment of 3 December 1996, ECLI:EU: C:1996:461, paras. 23-24.
} 
cooperation could include the objective of respect of human rights, as mentioned above. Now, Article 21 (2) TEU rules that 'the Union shall define and pursue common policies and actions, and shall work for a high degree of cooperation in all fields of international relations ${ }^{48}$, in order to consolidate and support human rights. This means that Article 21 TEU can be considered as a horizontal clause for protection of human rights in the EU's external relations. As a result, a human rights consideration should be seen in all the EU's external activities.

The following is an example. Article 209 TFEU is an article for development cooperation, while Article 212 TFEU is for economic, financial, and technical cooperation with third countries. Based on Articles 209 and 212 TFEU, Regulation No 235/2014, establishing a financing instrument for democracy and human rights worldwide, has been adopted by the EP and the Council. ${ }^{49}$ In its preamble, the regulation refers to the EU's values in Article 2 TEU and principles in Article 21 TEU, and protection of human rights as an objective is emphasised.

\subsubsection{Article 207 TFEU: The CCP}

The Common Commercial Policy (CCP) is one of the oldest policies regulated with the establishment of the EEC in 1958. The CCP was laid down in Article 113 Treaty establishing the EEC (TEEC). Article 113 TEEC has had amendments several times since then. Since the Treaty of Lisbon, Article 207 TFEU governs the CCP. ${ }^{50}$ Currently, not only traditional trade but also foreign direct investment, as well as the commercial aspect of intellectual property and trade in service, belong to the CCP's framework. The EU has exclusive competences in this field (Article 3 (1) (e) TFEU).

How can Article 207 TFEU for the CCP be a legal basis for concluding international agreements which contain human rights provisions? Marx, Natens, Geraets, and Wouters say that under Article 21 TEU, the Union must pursue international policies and actions inter alia to consolidate democracy, the rule of law, and human rights, and to preserve and improve the quality of the environment and the sustainable management of global natural resources. ${ }^{51}$ They indicate that these objectives apply to the CCP. ${ }^{52}$ Cremona observes that the CCP now also has an explicit sustainable development and human rights mandate derived from Article 21 TEU. ${ }^{53}$ Larik also indicates that in the CCP, the Union speaks with one voice on the international stage, and the message it is constitutionally mandated to spread globally is to be found in Articles 21 and 3 (5) TEU. ${ }^{54}$ Academics agree that human

\footnotetext{
${ }^{48}$ Emphasis by the author.

${ }^{49} \mathrm{OJ}$ of the EU 2014 L77/85.

${ }^{50}$ For details, see Bungenberg and Herrmann (2013).

${ }^{51}$ Marx et al. (2015, p. 4).

${ }^{52}$ Ibid., Marx et al. (2015, p. 4).

${ }^{53}$ Cremona (2014, p. 19).

${ }^{54}$ Larik (2015, p. 65).
} 
rights issues can or even must be included in the CPP according to Article 21 TEU. That means that Article 21 TEU cannot create or extend competence for human rights, but it mandates the Commission to negotiate on human rights issues in the context of trade and to include human rights considerations in agreements. In fact, the Free Trade Agreements (FTAs) which the EU has concluded or is negotiating with third countries after Lisbon contain definite human rights provisions. Further, the CJEU clarified in Opinion 2/15 regarding the FTA between the EU and Singapore that the CCP should be conducted in the principles and objectives in Article 21 (1) and (2) TEU and therefore the provisions regarding social and environmental issues fall within the scope of the CCP. ${ }^{55}$ It shows substantial changes of the CCP after the Treaty of Lisbon. The CJEU recognized those changes by itself.

There is, furthermore, an example of the CCP measure where human rights are related. On 14 April 2014, the Council adopted a Decision on the signing, on behalf of the EU, of the Marrakesh Treaty to facilitate access to published works for persons who are blind, visually impaired, or otherwise print disabled. The Council Decision 2014/221 is based on Articles 114 and 207 TFEU. ${ }^{56}$ According to its preamble (5) of the Decision, the Council indicates that the Marrakesh Treaty should be signed on behalf of the Union as regards matters falling within the Union's competence.

\subsection{International Human Rights Agreements}

\subsubsection{General}

The EU needs specific competences to conclude international human rights agreements. Those competences cannot be derived from the EU's values, principles, or objectives. As mentioned above, any specific competence for it was not given to the EU. The CJEU clarified this in Opinion 2/94 in $1996 .^{57}$ The EU (formerly the Community) could not accede to the ECHR because of a lack of competence. Does the Treaty of Lisbon lay down new competences for that? Now, Article 6 (2) TEU lays down that the EU shall accede to the ECHR. The means that the EU may not only accede to the ECHR, but also must accede to it, although the EU is not yet a Member of the ECHR. ${ }^{58}$ Article 6 (2) TEU rules specifically, that is, it refers only to accession to the ECHR.

\footnotetext{
${ }^{55} \mathrm{CJEU}$, Opinion 2/15, FTA between the EU and Singapore, Opinion of 16 May 2017, ECLI:EU: C:2017:376, paras. 141-142 and 167.

${ }^{56} \mathrm{OJ}$ of the EU $2014 \mathrm{~L} 115 / 1$.

${ }^{57}$ CJEU, Opinion 2/94, supra note (28).

${ }^{58} \mathrm{CJEU}$, Opinion 2/13, Accession to the ECHR, Opinion of 18 December 2014, ECLI:EU: C:2014:2454; The CJEU judged that the draft of the accession agreement was not compatible with the TEU and the TFEU.
} 
Does the EU have competences to conclude international human rights agreements generally? In particular, Article 19, 114, 82-86 and 352 TFEU are discussed. Article 19 TFEU provides a legal basis for non-discrimination. Article 114 TFEU provides a legal basis for the approximation of measures for the establishment and functioning of the internal market. Article 82-86 TFEU are new provisions for judicial cooperation in criminal matters since the Treaty of Lisbon. Article 352 TFEU has been considered as a potential competence to pursue an objective of the EU.

\subsubsection{Article 19 TFEU and Article 114 TFEU}

Just before the entry into force of the Treaty of Lisbon on 26 November 2009, the Council adopted a decision concerning the conclusion of the United Nations Convention on the Rights of Persons with Disabilities (hereinafter referred to as the UN Convention). ${ }^{59}$ This UN Convention is one of the international human rights agreements or international agreements on human rights. The Council decision 2010/48/EC is based on Article 13 TEC (now Article 19 TFEU) and Article 95 TEC (now Article 114 TFEU). According to its preamble (7), the Community (now the Union) and its Member States have competences in the fields covered by the UN Convention. Article 4 of the Decision lays down that with respect to matters falling within the Community's exclusive competence, the Union shall represent the Community at meeting of the bodies created by the UN Convention and, on the other hand, with respect to matters falling within the shared competences of the Union and the Member States, the Community and the Member States shall determine in advance the appropriate arrangements for representation of the Union's position at meetings of the bodies. This means that the EU had both partly exclusive and partly shared competences partly in concluding the UN Convention.

The Council may take appropriate action unanimously to combat discrimination based on sex, racial or ethnic origin, religion or belief, disability, age, or sexual orientation according to Article 19 TFEU (former Article 13 TEC). This legal basis can be used with other legal bases cumulatively. ${ }^{60}$ Article 19 TFEU also can be used as an independent legal basis. Article 13 TEC (now Article 19 (1) TFEU) was inserted in the Treaty by the Treaty of Amsterdam in $1999 .{ }^{61}$ Article 13 (2) TEC (now Article 19 (2) TFEU) was added in the TEC by the Treaty of Nice in 2003. Article 19 TFEU has, furthermore, a lot of potential for the concluding of international agreements on human rights.

Article 114 TFEU (former Article 95 TEC) is a legal basis for the establishment and functioning of the internal market. This Article has been applied conveniently

\footnotetext{
${ }^{59}$ Council of the EU, Council Decision of 26 November 2009 (2010/48/EC), OJ of the EU 2010 L23/35.

${ }^{60}$ See, Streinz (2012), Art. 19 AEUV, Rn. 3; there is also an opinion according to which Article 19 TFEU can be applied only in cases that there is not any other legal basis.

${ }^{61}$ Streinz (2012), Art. 19 AEUV, Rn. 1.
} 
for various measures ${ }^{62}$, although sometimes measures are challenged before the CJEU because of a lack of competences. ${ }^{63}$

Article 19 TFEU and Article 114 TFEU were relied on cumulatively to conclude the above-mentioned UN Convention. Article 19 TFEU regulates not only disability but also other types of discrimination. Each Article by itself and a combination of both Articles or can be legal basis further to conclude international agreements on human rights in the context of mainstreaming of human rights in the EU's external relations.

\subsubsection{Articles 82-86 TFEU}

After the Treaty of Lisbon, the so-called third pillar is laid down in the TFEU (former TEC), while the so-called second pillar remains in the TEU. The third pillar was related to the areas of freedom, security, and justice, in particular, judicial cooperation on criminal matters (Chap. 4) and police cooperation (Chap. 5). Articles 82, 83, 84, 85, and 86 TFEU can be the legal bases for judicial cooperation measures.

The Commission made proposals for a Council Decision on the signing, on behalf of the EU, of the Council of Europe Convention on preventing and combating violence against women and domestic violence ${ }^{64}$ and on a Council Decision on the concluding of that. ${ }^{65}$ According to both proposals for the Convention, the legal bases of the Decisions are Articles 82 (2) and 84 TFEU. De Vido argues that, additionally, Article 19 TFEU should also be relied on. ${ }^{66}$ Article 82 (2) TFEU is a legal basis for establishing minimum rules for facilitating the mutual recognition of judgments and judicial decisions and police and judicial cooperation matters having a cross-border dimension. Article 84 TFEU is made use of to 'establish measures to promote and support the action of Member States in the field of crime prevention'.

Based on the new Articles 82-86 TFEU after the Treaty of Lisbon in the field of judicial cooperation, the EU can negotiate and conclude international agreements on human rights.

\footnotetext{
${ }^{62}$ Ex. Regulation 1007/2009 on trade in seal products, OJ of the EU 2009 L286/36; Council Decision (2014/221/EU) on the signing of the Marrakesh Treaty to facilitate access to published works for persons who are blind, visually impaired, or otherwise print disabled, OJ of the EU 2014 L115/1.

${ }^{63}$ Ex. As for advertising tobacco products, see CJEU, Case C-376/98, Germany v EP and Council, Judgment of 5 October 2000, ECLI:EU:C:2000:544; as for seal products, see Case T-526/10, Inuit Tapiriit Kanatami and others, Judgment of 25 April 2013, ECLI:EU:T:2013:215 and Case C-398/13 P, inuit Tapiriit Kanatami and others, Judgment of 3 September 2015, ECLI:EU: C:2015:535; as for an agency of the EU (ESMA), see CJEU, Case C-270/12, UK v EP and Council, Judgment of 22 January 2014, ECLI:EU:C:2014:18.

${ }^{64}$ European Commission, COM (2016)111, 4 March 2016.

${ }^{65}$ European Commission, COM (2016)109, 4 March 2016.

${ }^{66}$ The Convention is also referred to as the Istanbul Convention on Preventing and Combating Violence against Women and Domestic Violence. For details, see De Vido (2017).
} 


\subsubsection{Article 352 TFEU}

In the past, the CJEU certainly clarified in Opinion 2/94 the legal character and limitations of Article 235 TEC (now Article 352 TFEU). The Court said that Article 235 TEC could not be used as a legal basis for accession to the ECHR, 'whose effect would, in substance, be to amend the Treaty without following the procedure which it provides for that purpose'. ${ }^{67}$ Furthermore, the CJEU indicated that respect for human rights was a condition of the lawfulness of the Community acts, but accession to the Convention would, however, entail a substantial change in the Community system for the protection of human rights. ${ }^{68}$ Finally, the CJEU judged that such a modification to the system for the protection of human rights in the Community would be of constitutional significance and would, therefore, be such as to go beyond the scope of Article 235 TEC. ${ }^{69}$

However, the situation changed after the Treaty of Lisbon. Concluding international agreements on human rights will not bring substantial change in the Union system for the protection of human rights. As mentioned above, protection of human rights belongs to the EU's values and means a concretisation of political principles and accomplishment of the EU's objectives. Article 352 TFEU is considered as a potential competence. For example, an EU Agency for Fundamental Rights was established by Council Regulation 168/2007, the legal basis of which was Article 308 TEC (now Article 352 TFEU). ${ }^{70}$ Article 352 (1) TFEU rules: "if action by the Union should prove necessary ... to attain one of the objectives set out in the Treaties, and the Treaties have not provided the necessary powers, the Council ... shall adopt the appropriate measures". Protection of human rights is now one of the most important objectives of the EU. Article 352 TFEU could be a legal basis for international agreements on human rights under the conditions and procedure of that Article, respecting the principle of conferral.

\section{Conclusions}

Already in 2004, Eeckhout had observed that human rights concerns were increasingly being integrated into the many different dimensions of EU external actions (mainstreaming), and that a growing number of instruments were being used to consolidate democracy and the rule of law and to further human rights protection. $^{71} \mathrm{He}$ also noted that unfortunately, however, there were significant

\footnotetext{
${ }^{67} \mathrm{CJEU}$, Opinion 2/94, supra note (28), para. 30.

${ }^{68}$ Ibid., para. 34 .

${ }^{69}$ Ibid., para. 35 .

${ }^{70}$ Council Regulation 168/2007 of 15 February 2007 establishing a European Union Agency for Fundamental Rights, OJ of the EU 2007 L53/1.

${ }^{71}$ Eeckhout (2004, p. 473).
} 
constitutional hurdles on the road towards a more meaningful external human rights policy, and the EU's powers in this field were much disputed in light of the importance of human rights for the federal balance between the EU and its Member States. $^{72}$ This was true then.

Leino points out that human rights are presented as a subject of shared interest. ${ }^{73}$ The EU seeks to develop relations and build partnerships with third countries and organisations that share the political principles expressed in Article $21 \mathrm{TEU}^{74} \mathrm{He}$ observes that, in practice, this is realised both through the mainstreaming of human rights into EU foreign policy and by making human rights considerations an aspect of international agreements concluded by the EU. ${ }^{75}$ This is true today.

The Treaty of Lisbon enables this. On the one hand, the EU has its own values in Article 2 TEU, sets out the political principles which should be applied in its external actions in Article 21 (1) TEU, and lays down comprehensive objectives in this field in Articles 3 (5) and 21 (2) TEU. For example, sustainable development including human rights issues can be inserted in the FTA and those issues fall within the scope of the CCP in connected to Article 21 (1) and (2) TEU. The CJEU confirmed it in Opinion $2 / 15$. $^{76}$

On the other hand, the EU has new competences for judicial cooperation in Articles 82-86 TFEU. They can be relied on for concluding international agreements on human rights. Article 19 TFEU and/or Article 114 TFEU can also be relied on for those agreements. Article 207 in the CCP and other Articles in other policies can be used in the context of strengthening support of human rights in combination with Article 2 TEU, Article 3 (5) TEU, and Article 21 TEU. Furthermore, Article 352 TFEU has a lot of potential to form a legal basis for concluding international agreements on human rights in combination with Article 2 TEU, Article 3 (5), and Article 21 TEU. Those changes after the Treaty of Lisbon enable the EU to mainstream human rights in the EU's external relations. It can also be said that Article 21 TEU plays a role as an instrument for cross-fertilisation in the context of human rights.

\section{References}

Bartels L (2015) Human rights and sustainable development obligations in EU free trade agreements. In: Wouters J, Marx A, Geraets D, Natens B (eds) Global governance through trade. Edward Elgar, Cheltenham, pp 73-91

Bungenberg M, Herrmann C (2013) Common commercial policy after Lisbon. Springer, Berlin Cremona M (2011a) Coherence in European Union foreign relations law. In: Koutrakos P (ed) European foreign policy. Edward Elgar, Cheltenham, pp 55-92

\footnotetext{
${ }^{72}$ Ibid., Eeckhout (2014, p. 483).

${ }^{73}$ Leino (2008, p. 263).

${ }^{74}$ Ibid., Leino (2008, p. 261).

${ }^{75}$ Ibid., Leino (2008, p. 261).

${ }^{76} \mathrm{CJEU}$, Opinion 2/15, supra note (55), paras. 141-142.
} 
Cremona M (2011b) Values in EU foreign policy. In: Evans M, Koutrakos P (eds) Beyond the established legal orders. Hart Publishing, Oxford, pp 275-315

Cremona M (2014) A reticent court? Policy objectives and the court of justice. In: Cremona M, Thies A (eds) The European Court of Justice and external relations law. Hart Publishing, Oxford, pp 15-32

Dashwood A (2008) Article 47 TEU and the relationship between first and second pillar competences. In: Dashwood A, Maresceau M (eds) Law and practice of EU external relations. Cambridge University Press, Cambridge, pp 70-103

De Vido S (2017) The ratification of the Council of Europe Istanbul Convention by the EU: a step forward in the protection of women from violence in the European legal system. Eur J Legal Stud (EJLS) 9(2):69

Eeckhout P (2004) External relations of the European Union. Oxford University Press, Oxford

Eeckhout P (2014) The European convention on human rights and fundamental freedoms as an integral part of EU law-some reflections on status and effect. In: Govaere IE, Lannon P, Elsuwege V, Adam S (eds) The European Union in the world, essays in honour of Marc Maresceau. Martinus Nijhoff Publisher, Leiden, pp 87-99

Herlin-Karnell E (2014) EU values and the shaping of the international legal context. In: Kochenov D, Amtenbrink F (eds) The European Union's shaping of the international legal order. Cambridge University Press, Cambridge, pp 89-107

Koutrakos P (2015) EU international relations law, 2nd edn. Hart Publishing, Oxford

Larik J (2014) Shaping the international order as an EU objective. In: Kochenov D, Amtenbrink F (eds) The European Union's shaping of the international legal order. Cambridge University Press, Cambridge, pp 62-86

Larik J (2015) Good global governance through trade: constitutional moorings. In: Wouters J, Marx A, Geraets D, Natens B (eds) Global governance through trade. Edward Elgar, Cheltenham, pp 43-69

Leino P (2008) The journey towards all that is good and beautiful: human rights and 'common values' as guiding principles of EU foreign relations law. In: Cremona M, Witte B (eds) EU foreign relations law. Hart Publishing, Oxford, pp 259-289

Marx A, Natens B, Geraets D, Wouters J (2015) Global governance through trade: an introduction. In: Wouters J, Marx A, Geraets D, Natens B (eds) Global governance through trade. Edward Elgar, Cheltenham, pp 1-15

Murswiek D (2011) Das Lissabon-Urteil des Bundesverfassungsgerichts aus der Sicht eines Prozessvertreters Reflexionen zu Demokratie und Souveränität in Europa. In: Appel I, Hermes G, Schönberger C (eds) Öffentliches Recht im offenen Staat, Festschrift für Wahl zum 70. Geburtstag. Duncker \& Humblot, Berlin, pp 779-801

Nakanishi Y (2014) Political principles in Article 21 TEU and constitutionalism. Hitotsubashi J Law Politics 42:11-23

Nakanishi Y (2016a) The principle of animal welfare in the EU and its influence in Japan and the world. In: Nakanishi Y (ed) Contemporary issues in environmental law. Springer, Tokyo, pp 87-113

Nakanishi Y (2016b) Animal welfare in the European Union's external relations law. In: Weaver J (ed) Animal welfare. Nova Science Publishers, New York, pp 125-145

Neframi E (2014) Vertical division of competences and the objectives of the European Union's external action. In: Cremona M, Thies A (eds) The European Court of justice and external relations law. Hart Publishing, Oxford, pp 73-94

Reid E (2015) Balancing human rights, environmental protection and international trade. Hart Publishing, Oxford

Streinz R (2012) Art. 19. In: Streinz R (ed) EUV/AEUV Kommentar, 2 Aufl. C.H. Beck, München

Weatherill S (2016) Law and values in the European Union. Oxford University Press, Oxford

Wouters J, Odermatt J, Ramopoulos T (2014) Worlds apart? Comparing the approaches of the European Court of Justice and the EU Legislature to international law. In: Cremona M, Thies A (eds) The European Court of Justice and external relations law. Hart Publishing, Oxford, pp 249-279 


\section{Author Biography}

Yumiko Nakanishi is professor of European Union Law at Graduate School of Law, Hitotsubashi University, Tokyo. She studied European law at Hitotsubashi University and Münster University (Germany). She got Master of law (Hitotsubashi University 1993), Magister Legum (University of Münster 1995) and Doctor of law (University of Münster 1998). She is a member of the board of directors of the European Union Studies Association-Japan, member of Japan Association of Environmental Law and Policy, member of Japanese Society of International Law. She is founder and representative of Hitotsubashi Association of European Union Law. She is chief editor of the journal Review of European Law. Her fields of research are EU constitutional law, EU environmental law and EU external relations law. Her publications include the following. Books: Contemporary Issues in Environmental Law-The EU and Japan, Springer 2016; Collection of Case Law Analysis regarding EU Competences, Shinzansha 2015 (in Japanese); Legal Structure of EU Competences, Shinzansha 2013 (in Japanese); European Union Law, Shinseisha, Tokyo 2012 (in Japanese). Articles: Completion of EU measures through court decisions: the example of the European arrest warrant, Hitotsubashi Journal of Law and Politics, vol. 45, 2017, Feburary, pp. 13-21; Japanese environmental law in the context of globalization-a focus on chemical law, in Alexander Proel $\beta$ and others (ed.) Protecting the Environment for Future Generations-Principles and Actors in International Environmental Law, Berlin, Erich Schmidt Verlag 2017, pp. 283-304; Animal welfare in the European Union's external relations law, in Jeremiah Weaver (ed.) Animal Welfare, Nova Science Publishers 2016, pp. 125-145; Introduction: The impact of the international and European environmental law on Japanese basic environmental law, pp. 1-13, The principle of animal welfare in the EU and its influence in Japan and the world, pp. 87-113, in Y Nakanishi (ed.) Contemporary Issues in Environmental Law, Springer 2016; Economic partnership agreement between Japan and the European Union and legal issues, Hitotsubashi Journal of Law and politics, Vol. 44, 2016, pp. 19-30; Political principles in article 21 TEU and constitutionalism, Hitotsubashi Journal of Law and Politics, Vol. 42, 2014, pp. 11-23; Characteristics of free trade agreements of the EU in the legal context: a Japanese perspective, European Yearbook of International Economic Law, Springer 2017 (forthcoming).

Open Access This chapter is licensed under the terms of the Creative Commons Attribution-NonCommercial-NoDerivatives 4.0 International License (http://creativecommons. org/licenses/by-nc-nd/4.0/), which permits any noncommercial use, sharing, distribution and reproduction in any medium or format, as long as you give appropriate credit to the original author (s) and the source, provide a link to the Creative Commons license and indicate if you modified the licensed material. You do not have permission under this license to share adapted material derived from this chapter or parts of it.

The images or other third party material in this chapter are included in the chapter's Creative Commons license, unless indicated otherwise in a credit line to the material. If material is not included in the chapter's Creative Commons license and your intended use is not permitted by statutory regulation or exceeds the permitted use, you will need to obtain permission directly from the copyright holder.

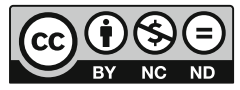

